\title{
ŠTÁTNY ARCHEOLOGICKÝ ÚSTAV V TURČIANSKOM SV. MARTINE V ROKOCH 1939-1953
}

\section{MARTIN NEUMANN}

Abstrakt: Profesionalizácia archeologického bádania na Slovensku sa začina so vznikom samostatnej Československej republiky. Vyvrcholenie týchto snáh, stelesnené vznikom Štátneho archeologického ústavu v Turčianskom Sv. Martine, je však úzko previazané až s pomerne neskorým obdobím rokov 1938-1939. Archívny výskum, ktorého výsledky sú prezentované v tejto štúdii, priniesol nový a ucelenejši pohl'ad na formujúce roky tejto dodnes existujúcej inštitúcie. Pozornost' je venovaná najmä začiatkom ústavu, jeho počiatočným finančným, personálnym i priestorovým problémom v rozmedzi rokov 1939-1953. Príspevok si kladie za ciel' predovšetkým sprístupnit' doposial' nepublikované informácie o živote Štátneho archeologického ústavu, a tým tak aspoň čiastočne zaplnit' medzeru v bádaní o dejinách archeologických inštitúcií na Slovensku.

Kl'účové slová: Vojtech Budinský-Krička - Štátny archeologický ústav - Slovenské národné múzeum - Muzeálna slovenská spoločnost'-dejiny archeológie.

\section{The State Archaeological Institute in Turčiansky Sv. Martin in 1939-1953}

Abstract: The professionalization of archaeological study in Slovakia started with the establishment of the independent Czechoslovak Republic (1918). However, these efforts, epitomised by the foundation of the State Archaeological Institute in Turčiansky Sv. Martin, only culminated relatively late, in the years 1938-1939. Archive research the results of which are presented in this study brought a new and more comprehensive insight into the formative years of this institution which has existed to this day. Attention is mainly devoted to the beginnings of the institute, its initial financial, staff and location-related problems in the years 1939-1953. Above all, the article seeks to make accessible unpublished information about the activities of the State Archaeological Institute, thus at least partially bridging a gap in research into archaeological institutions in Slovakia.

Key words: Vojtech Budinský-Krička - State Archaeological Institute - Slovak National Museum - Slovak Museum Society - history of archaeology.

\section{Úvod}

Kým rok 2018 bol rokom stého výročia vzniku Československej republiky, v roku 2019 si česká a slovenská archeologická obec pripomína vznik kl’účových štátnych archeologických inštitúcií - Štátneho archeologického ústavu v Prahe (1919) a Štátneho archeologického ústavu v Turčianskom Sv. Martine (1939). Zhodou okolností ich vznik v hrubých rysoch rámcuje trvanie 1. Československej republiky. Rok 1939 bol však do istej miery osudový pre obe časti niekdajšej spoločnej republiky. V Protektoráte Čechy a Morava síce aj nad'alej existoval Štátny archeologický ústav, no už pod nemeckou kontrolou - v roku 1941 bol Lothar Zotz poverený dohl'adom nad záujmami nemeckej archeológie v Protektoráte a zároveň mohol dohliadat' na terénne aktivity ústavu (Starcová 2019, 68-69). Politickú kontrolu priamo na ústave vykonávala v pozícii zástupkyne riaditel’a Camilla Streit (Oliva-Kostrhun 2019, 113). Na Slovensku nebola situácia taká vážna. Založenie a ani riadenie Štátneho archeologického ústavu sa neuskutočňovalo pod nemeckou taktovkou, hoci nemecká archeológia na Slovensku nesporne mala svoje záujmy. Budovanie samostatnej archeologickej inštitúcie a jej materiálny a vedecký rozvoj tak boli úplne v slovenských rukách. V nasledujúcom texte sa v krátkosti pokúsime načrtnút', ako sa rodiaca slovenská archeologická obec, v tom čase obmedzená len na zopár jednotlivcov, dokázala vysporiadat' s meniacimi sa spoločenskými podmienkami obdobia rokov 1939-1953. 


\section{Počiatky ústavu}

Vznik a prvé roky činnosti Štátneho archeologického ústavu boli úzko previazané so Slovenským národným múzeom v Turčianskom Sv. Martine (bližšie pozri Neumann 2019, 10-13). Pri jeho počiatkoch stála Muzeálna slovenská spoločnost' (d’alej len MSS), ktorá mala v rámci slovenskej intelektuálnej spoločnosti doznievajúceho 19. storočia plnit' funkciu akéhosi vedeckého spolku či dokonca akadémie vied. Na základe historickej skúsenosti so zatvorením Matice slovenskej a skonfiškovaním jej zbierok bola spoločnost' založená na spolkovom (súkromnom) základe a od štátu nepoberala žiadnu finančnú podporu (Kujovský-Vladár 2013, 189). Založením MSS sa zároveň položili základy spolkového múzea, z ktorého neskôr vzniklo Slovenské národné múzeum. Základom muzeálnych zbierok sa stali zbierky z už existujúceho Národného domu (Jurkovič 1945, 13-14). Samotná MSS mala mat' v prvom rade charakter vedeckej inštitúcie, čo sa patrične odrážalo i v jej stanovách (Hyčko-Okáli-Polla 1968, 9). Jej záujem sa týkal najmä duchovnej a hmotnej kultúry slovenského l'udu. Aby mohla byt' postihnutá vo všetkých svojich aspektoch, bola vedecká činnost' MSS organizovaná vo viacerých odboroch. Jedným z 12 odborov bol i odbor pre pravek, starožitnosti a antropológiu, ktorý stojí na počiatku organizovania profesionálnej archeológie na Slovensku (Hyčko-Okáli-Polla 1968, 10). Múzejné zbierky sa vd’aka darom členov i nečlenov MSS neustále zväčšovali a bolo nutné zabezpečit' odbornú starostlivost' o ne. Po peripetiách 1. svetovej vojny a následnom utlmenom vývoji MSS bol v múzeu koncom 20. rokov 20. storočia zamestnaný ako kustód historických zbierok Vojtech Budaváry (v múzeu sa však zaoberal výlučne archeológiou). Túto pozíciu zastával len do 1. mája 1933, kedy nastúpil do služieb Československého štátneho archeologického ústavu v Prahe na post komisára štátnej osvetovej služby. Hoci sa o obsadenie uvol’neného miesta kustóda hlásilo viacero záujemcov, výbor MSS nad’alej požadoval na toto miesto V. Budaváryho (Geryk 1929, 131; 1933, 31-33; 1933a, 66-74; 1935, 49-51). Ten totiž už dôverne poznal muzeálne zbierky, bol zbehlý v inventarizácii a navyše sa aktívne podiel'al na archeologických výskumoch. Avšak vd’aka novým akvizíciám sa postupom času neriešený problém s narastajúcimi zbierkami neustále stupňoval. Výbor MSS si uvedomil, že na jeho riešenie nebude sám stačit'. V dôsledku toho boli z iniciatívy MSS podnikané kroky, ktoré mali viest' k poštátneniu Slovenského národného múzea (Výročná správa 1939, 31-32; Hyčko-Okáli-Polla 1968, 14). Financovanie múzea by sa tak dostalo do štátnych rúk, čím sa otvárala cesta na financovanie odborných pracovníkov múzea a najmä dovtedy nehonorovaných kustódov zo štátneho rozpočtu a nie z prostriedkov MSS. Kustódi jednotlivých oddelení by tak mohli byt' priamymi zamestnancami múzea. S prevodom do štátnych rúk súhlasil aj Krajinský výbor. Na zasadnutí výboru a zhromaždenia MSS, ktoré sa konalo 4. augusta 1938, boli stanovené podmienky tohto prevodu. V dňoch 7.-9. septembra vyslal Krajinský úrad revíznu komisiu, ktorá mala zistit' tarchy a budúce náklady SNM. V rozpočte Slovenskej krajiny bolo na nasledujúci rok vyčlenených 500000 Ks na dlhy múzea ako i na jeho udržiavanie. Tieto snahy však narušil turbulentný politický vývoj na konci roka 1938. Dňa 6. októbra 1938 bola vyhlásená slovenská autonómia a v novembri bol zrušený krajinský výbor a krajinské zastupitel'stvo (Bianchi a kol. 1973, 494). Výbor MSS tak tesne pred prevodom stratil partnera, ktorý bol ochotný a pripravený prevziat' SNM pod svoju správu. V tejto situácii sa preto zdalo, že snahy MSS vyjdú nazmar.

Situáciu sa pokúsil iniciatívne zachránit' správca SNM a tajomník MSS v jednej osobe - Ján Geryk. Už krátko po vyhlásení autonómie adresoval J. Geryk list Ministerstvu školstva a národnej osvety Slovenskej krajiny (d’alej len MŠANO), v ktorom žiadal zriadenie Štátneho archeologického ústavu a obsadenie funkcie štátneho konzervátora osobou V. Budaváryho (Polla 1989, 126). Udalosti však akceleroval d’alší vývoj na politickej scéne. Dňa 23. decembra 1938 bolo vydané vládne nariadenie č. 382 , na základe ktorého mala slovenská vláda prevziat’ štátnych zamestnancov slovenskej národnosti pôsobiacich na území Českej a Moravsko-sliezskej krajiny do služieb Slovenskej krajiny (Vládne nariadenie 1938, § 6; obr. 1). Už v januári nasledujúceho roka J. Geryk požiadal ministra školstva a národnej osvety o zriadenie archeologického ústavu pri Slovenskom národnom múzeu, pričom za jeho riaditel’a navrhol V. Budaváryho. Jeho výber 


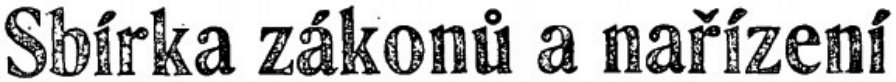

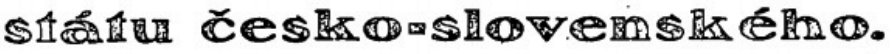

Cástka 120.

Vydána dne 30. prosince 1938.

Cena: Ǩ̌ 1.-

Obsah: 382. Nařizenf o úpravě některých služebních poměrủ státních zaměstnancủ se zřetelem $\mathrm{k}$ autonomii země Slovenské.

\section{2. \\ Vládni nařizení \\ ze dne 23. prosince 1938}

o úpravě některých služebních poměrů státních zaměstnanců se zřetelem $\mathbf{k}$ autonomii země Slovenské.

Vláda republiky Česko-Slovenské nařizuje podle čl. II ústavního zákona zmocňovacího ze dne 15. prosince 1938, č. 330 Sb. z. a n.:

\section{$\S 1$.}

Státní zaměstnanci české národnosti, jejichž úřední (služební) působiště bylo dne 7. října $1938 \mathrm{v}$ obvodu země Slovenské, budou v počtu nejvýše 9.000 osob převzati do obvodu země České nebo země Moravskoslezské.

\section{$\S 2$.}

(1) Zemská vláda slovenská urči $\mathrm{k}$ návrhu př́slušného ministerstva země Slovenské zaměstnance, kteři budou prevzati podle $\S 1$, a sdělí je nejpozději do 31 . prosince 1938 vládě republiky Česko-Slovenské; při tom je zásadou, že budou určeni především zaměstnanci, jichž další setrvání na Slovensku ze služebních přičin je nežádoucí, kteří dosud nejsou ustanoveni definitivně, zejména čekatelé, zaměstnanci prozatímní, zaměstnanci na zkoušku, zaměstnanci ve smluvním služebním poměru a zaměstnanci $\mathrm{v}$ podobném postavení.

(2) Příslušné ministerstvo země Slovenské učiní opatření, aby zaměstnanci určení podle předešlého odstavce byli zproštěni služby na Slovensku nejpozději dnem 31. března 1939.

\section{$\S 3$.}

(1) Zaměstnance uvedené v \$ 2 převezme do obvodu země Čské nebo zemĕ Moravskoslez- ské přislušný ústřední úřad, jehož působnost se vztahuje na tyto země, nebo úrad jím $\mathrm{k}$ tomu zmocněný. Př́islušným ústředním úřadem se tu rozumí ústřední úr̆ad, jehož působnost odpovídá dosavadnímu resortnímu zařadění zaměstnancovu.

(2) Zaměstnanci převzatí podle předcházejícího odstavce se zařadí v kategorii, ke které patří, do osobního stavu, systemisovaného v resortu příslušného ústředního úr̆adu (odst. 1) pro služební obor (úřad, ústav, podnik, zařízení), v němž budou umístěni. Není-li v tomto osobnim stavu pro ně volných systemisovaných služebních míst, budou vedeni nad systemisovaný stav a załadí se na systemisovaná služební místa, jakmile se taková uprázdní.

(3) Dnem následujícím po zproštění služby na Slovensku přecházeji veškerá práva a povinnosti země Slovenské a jejích úřadů a orgánů, vyplývajíci ze služebního poměru převzatých zaměstnanců, na př́slušné úřady a orgány vi zemích české a Moravskoslezské.

\section{$\S 4$.}

(1) Služebni pořadí zaměstnanců převzatých podle $\S 3$ upraví př́íslušný ústřední úŭad nebo úřad (orgán) jím $\mathrm{k}$ tomu zmocněný, a to i s účinkem pro všechny zaměstnance osobního stavu, do něhož budou prevzatí zaměstnanci zařaděni, tak, aby se vyrovnaly případné nesrovnalosti, které by $\mathrm{z}$ dosavadního služebního pořadí převzatých zaměstnanců vznikly v osobním stavu, o který jde.

(2) Služební pořadí určené podle předcházejícího odstavce platí tak dlouho, dokud nenastanou skutečnosti odůvodňující podle platných předpisů změnu služebního pořadí.

$\S 5$.

Zaměstnanci české národnosti, kteří nebudou zproštěni služby na Slovensku do 31 . březso zretel'om $k$ autonómii krajiny Slovenskej.

Abb. 1. Regierungsverordnung Nr. 382 vom 23. Dezember 1939 über die Reglung einiger Dienstverhältnisse von Staatsangestellten im Hinblick auf die Autonomie des Slowakischen Landes. 
bol pochopitel'ný - V. Budaváry pôsobil v SNM už v rokoch 1929-1933 a i po svojom odchode do Prahy sa každý rok počas letných mesiacov vracal spät' na Slovensko a viedol tu archeologické výskumy. Na základe nasledujúcich udalostí možno súdit', že príhovor J. Geryka našiel u ministra odozvu. V. Budaváry bol výnosom prezídia MŠANO zo dňa 17. februára 1939 prevzatý do služieb Ministerstva školstva a národnej osvety Slovenskej krajiny a začiatkom nasledujúceho mesiaca bol dekrétom č. 1562/1939-prez zriadený samostatný Štátny archeologický a konzervátorský ústav (v dobových dokumentoch i tlači bežne označovaný ako Štátny archeologický ústav). Riaditel'om ústavu bol v ten istý deň podl’a očakávania menovaný V. Budaváry (Archív SAV, AÚ SAV; Prehlad prác 1940, 28; faksimile dekrétu prezídia pozri v Polla 1989, 133).

\section{Zariad'ovanie ústavu}

Štátny archeologický ústav (d’alej ŠAÚ) bol zriadený pri Slovenskom národnom múzeu, ktoré v dôsledku politických zmien na konci roka 1938 aj nad’alej zotrvávalo v súkromných rukách (obr. 2). Nastala tak paradoxná situácia, kedy štátna inštitúcia - ŠAÚ - fungovala pod záštitou spolkového múzea. Markantne sa to prejavovalo v materiálnom zabezpečení ústavu. V. Budavárymu sa po dohode so Správou SNM podarilo v priestoroch múzea určit' miestnost', ktorá mala slúžit' ako pracovňa a úradovňa riaditel'a ústavu. Samostatná miestnost' bola vyčlenená aj pre doposial' nespracovaný archeologický materiál. O vnútorné zariadenie miestností sa mala postarat' MSS. Riaditel' ŠAÚ dostal k dispozícii aj príručnú múzejnú knižnicu, laboratórium, preparátora a niekol'ko kancelárskych síl (Archív SAV, AÚ SAV a). Ďalšie výdavky ŠAÚ, predovšetkým tie súvisiace $\mathrm{s}$ administratívou, malo hradit' ministerstvo. V. Budaváry žiadal oficiálnou cestou o dodanie úradnej pečiatky, papiera, obálok, prírastkových kníh, protokolu, lístkovej kartotéky, fotografického materiálu a tiež v tej dobe nevyhnutného kríža (Archív SAV, AÚ SAV b). Finančné zaistenie každodenného chodu ŠAÚ malo poskytovat' formou štvrt'ročných dotácií MŠANO. Dotácie boli členené na štyri časti a pokrývali náklady na cestovné a stravné, úradné a kancelárske potreby, archív s knižnicou a so zbierkami a napokon výdavky na ochranné práce a vykopávky. Množstvo pridel'ovaných dotácií však bolo jednoznačne nedostatočné. Výška prvého štvrt'ročného príspevku za rok 1940 činila spolu $3000 \mathrm{Ks}$ a v priebehu nasledujúcich rokov rástla len vel'mi pomaly (Archív SAV, AÚ SAV c). Prvý „povojnový“ štvrt'ročný príspevok, pridelený v máji 1945 Povereníctvom pre školstvo a osvetu, dosahoval výšku 4750 Ks (Archív SAV, AÚ SAV d). Samozrejme, poskytované dotácie nestačili na dostatočné materiálne zabezpečenie ústavu a zaistenie jeho riadneho chodu. $\mathrm{V}$ dôsledku toho bol V. Budaváry nútený pravidelne žiadat' MŠANO o mimoriadne príspevky. Aby si mohol ústav dovolit' zakúpenie fotografického prístroja, expozimetra, buzoly, hranola, výškomeru a nivelačného prístroja, pýtal v roku 1940 od ministerstva $6000 \mathrm{Ks}$ (Archív SAV, AÚ SAV e). Vel'kú pomoc, predovšetkým pri realizovaní archeologických výskumov, poskytovali dary od súkromných osôb či inštitúcií. V roku 1940 darovala Šarišsko-zemplínska župa sumu 4000 Ks na archeologický výskum v Kožanoch (Archív SAV, AÚ SAV f). O rok neskôr schválil župný úrad Prešovskej župy pridelenie $10000 \mathrm{Ks}$ na výskum v Zemplíne (Archív SAV, AÚ SAV g). Čiastku 12000 Ks poukázal v roku 1942 na účet Štátneho archeologického ústavu Ján Mjartan, čo sa rovnalo výške vtedajšej ročnej dotácie (Archív SAV, AÚ SAV h). Činnost’ Štátneho archeologického ústavu podporil koncom roka 1943 aj podnik Bata, a to sumou vo výške $5000 \mathrm{Ks}$ (Archív SAV, AÚ SAV i).

Náročnú organizačnú prácu v ústave musel V. Krička ${ }^{1}$ zvládat’ od začiatku sám. Až v marci roku 1941 sa mu podarilo získat' prvého pomocného zamestnanca - Andreja Rajniča (Archív SAV, AÚ SAV j; Pavúk 2004, 187). Nedostatočné personálne obsadenie ústavu musel preto V. Krička riešit' inak. Podarilo sa mu takmer po celom Slovensku vytvorit' siet' spolupracovníkov, ktorí ochotne zastupovali ŠAÚ vo svojich regiónoch (obr. 3). Ich právne postavenie v rámci štruktúry ústavu bolo kodifikované vo výnose MŠANO z 8. mája 1942. Spolupracovníci ústavu dostali

1 V. Budaváry si medzitým zmenil priezvisko na Krička, neskôr na Budinský-Krička. 


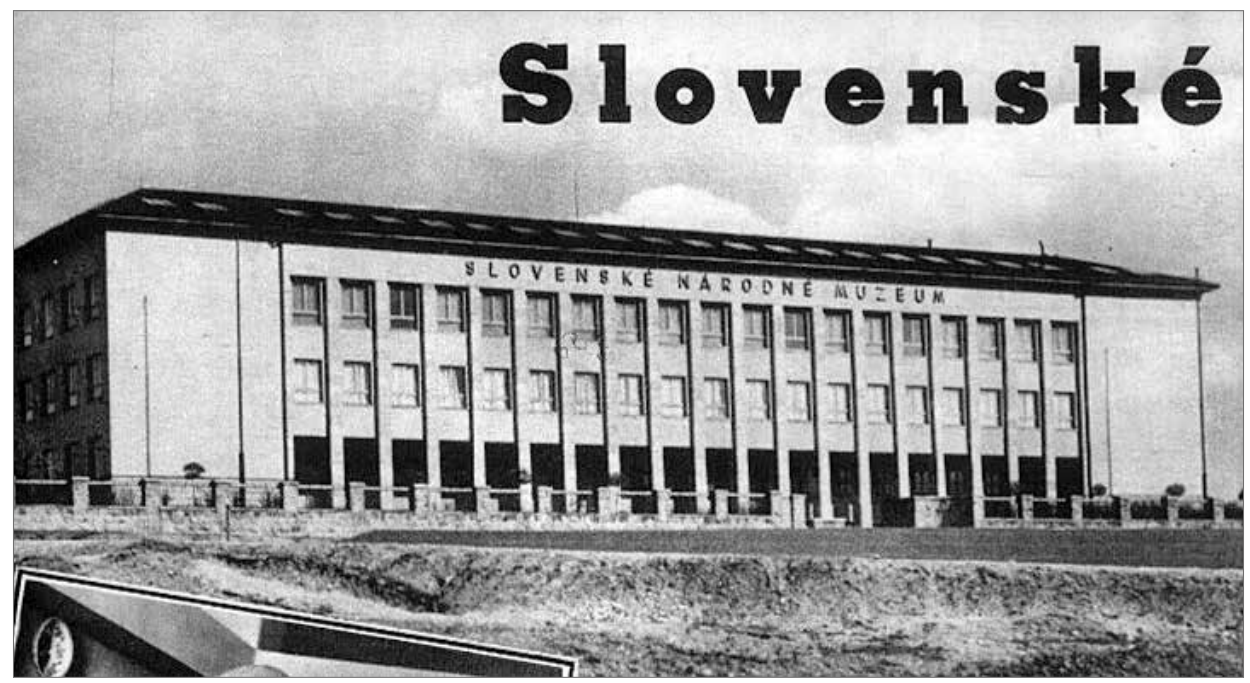

Obr. 2. Budova Slovenského národného múzea v Turčianskom Sv. Martine. V nej mal svoje sídlo aj Štátny archeologický ústav. Zdroj Nový svet, 31. máj 1941.

Abb. 2. Gebäude des Slowakischen Nationalmuseums in Turz-Sankt Martin. In ihm hatte auch das Staatliche archäologische Institut seinen Sitz. Quelle Nový svet, 31. Mai 1941.

štatút tajomníkov. Bola to čestná funkcia, ktorú pridel’oval minister školstva a národnej osvety na návrh riaditela ŠAÚ. Poslaním tajomníka bolo zastupovat' ústav a informovat' jeho riaditela o archeologických nálezoch vo svojom regióne (Archív SAV, AÚ SAV k). Takto bolo počas druhej svetovej vojny činných na Slovensku 18 tajomníkov, medzi nimi napríklad Viktor Šemmer, Dezider Tomeček, Ernest Opluštil, Šarlota Križanová, Gejza Balaša, Štefan Janšák či Luudmila Kraskovská.

\section{Medzi povstaním a prechodom frontu}

S príchodom jesene roku 1944 nastali pre ústav t’ažké časy. Vd’aka svojej polohe sa po vypuknutí Slovenského národného povstania ocitol takmer v strede povstaleckého územia. V septembri 1944 sa v súvislosti s postupom nemeckých jednotiek smerom k Turčianskemu Sv. Martinu začalo s evakuáciou archeologických zbierok, ktoré boli inštalované v SNM. Debny so starostlivo zabalenými zbierkovými predmetmi boli prezieravo uložené v suteréne múzea, kde našli bezpečný úkryt (Archív SAV, AÚ SAV 1). Tento krok sa neskôr ukázal ako opodstatnený. Nemecké ostrelovanie Turčianskeho Sv. Martina postihlo aj budovy SNM, ktoré boli zasiahnuté deviatimi strelami (Geryk 1946, 11). Ďalších sedem striel dopadlo do susednej botanickej záhrady (Halmová $2015,10)$. Explózie poškodili prednáškovú sieň, mineralogické zbierky, schodisko, terasu a sieň venovanú zvykosloviu. Archeologické zbierky zostali uchránené pred poškodením, ked’že boli už uložené v debnách v suteréne. V budove múzea z príkazu správcu múzea Jána Geryka zotrvával len múzejný sprievodca Pavol Janíček, ktorý mal ukryté zbierky strážit'. Nemecké protipovstalecké jednotky prišli do SNM až 21. septembra. Podvečerná návšteva jedenástich nemeckých vojakov zostala bez akýchkol’vek následkov (Geryk 1946a, 6). Nasledujúci deň sa však situácia zmenila. Násilím vniknuvšia skupina vojakov začala vo výstavných sieňach múzea stavat' barikády a na terase múzea vytvorila gulometnú pozíciu. Ďalšie gulomety boli postavené aj na prvom a tretom poschodí, kde bývala umiestnená archeologická expozícia. Po odznení povstania zostali debny aj nad’alej zamurované v suteréne. Budova múzea dočasne slúžila ako ubytovňa pre 


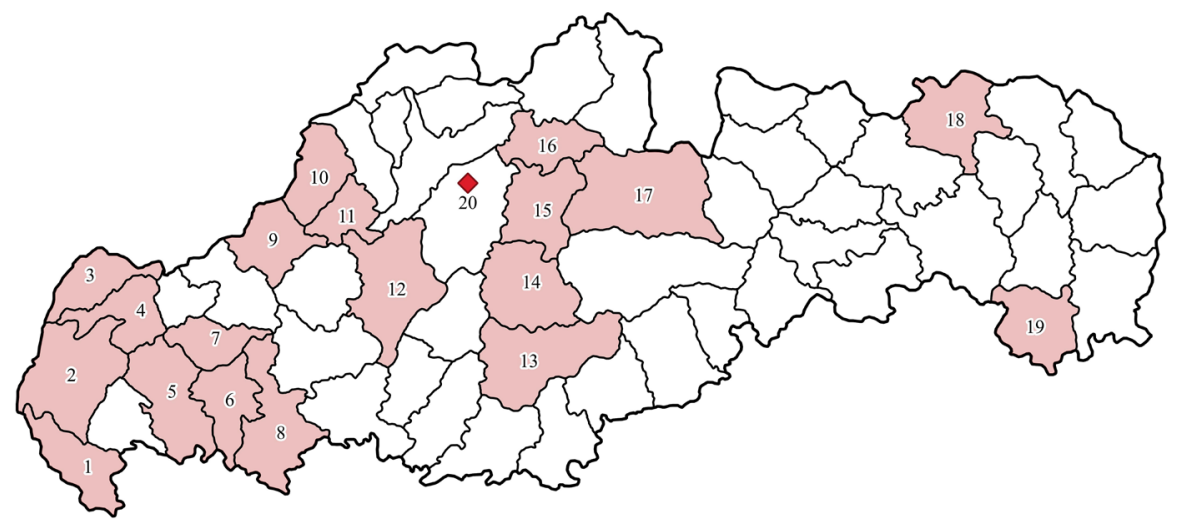

Obr. 3. Siet’ tajomníkov spolupracujúcich so Štátnym archeologickým ústavom (stav k roku 1943). 1 - Ludmila Kraskovská, Štefan Janšák (okr. Bratislava); 2 - Dezider Tomeček (okr. Malacky); 3 - Koloman Sopko (okr. Skalica); 4-6 - Viktor Šemmer (okr. Senica, Trnava, Hlohovec); 7 - Arnošt Opluštil (okr. Piešt’any); 8 - Jozef Karvaš (okr. Nitra); 9 - Štefan Pozdišovský (okr. Trenčín); 10-11 - Šarlota Križanová (okr. Púchov nad Váhom, Ilava); 12 - Gregor Králik (okr. Prievidza); 13 - Štefan Balaša (okr. Zvolen); 14 - Karol Kiszely (okr. Banská Bystrica); 15 - Jozef Jakubík (okr. Ružomberok); 16 - Ludovít Garaj (okr. Dolný Kubín); 17 - Ján Volko-Starohorský (okr. Liptovský Sv. Mikuláš); 18 - Bartolomej Krpelec (okr. Bardejov); 19 Ján Némethy (okr. Trebišov); 20 - sídlo Štátneho archeologického ústavu v Turčianskom Sv. Martine. Autor M. Neumann.

Abb. 3. Netzwerk der mit dem Staatlichen archäologischen Institut zusammenarbeitenden Sekretäre. Stand zum Jahr 1943. 1 - Ludmila Kraskovská, Štefan Janšák (Bezirk Bratislava); 2 - Dezider Tomeček (Bezirk Malacky); 3 - Koloman Sopko (Bezirk Skalica); 4-6 - Viktor Šemmer (Bezirk Senica, Trnava, Hlohovec); 7 - Arnošt Opluštil (Bezirk Piešt'any); 8 - Jozef Karvaš (Bezirk Nitra); 9 - Štefan Pozdišovský (Bezirk Trenčín); 10-11 - Šarlota Križanová (Bezirk Púchov nad Váhom, Ilava); 12 - Gregor Králik (Bezirk Prievidza); 13 - Štefan Balaša (Bezirk Zvolen); 14 - Karol Kiszely (Bezirk Banská Bystrica); 15 - Jozef Jakubík (Bezirk Ružomberok); 16 - Ludovít Garaj (Bezirk Dolný Kubín); 17 - Ján Volko-Starohorský (Bezirk Liptovský Sv. Mikuláš); 18 - Bartolomej Krpelec (Bezirk Bardejov); 19 - Ján Némethy (Bezirk Trebišov); 20 - Sitz des Staatlichen archäologischen Instituts in Turz-Sankt Martin. Zusammengestellt von M. Neumann.

nemocničný personál, od januára 1945 tu dokonca prebiehala výučba gymnaziálnych študentov (Geryk 1946a, 8). Krušné chvíle sa však pre múzeum ešte nemali skončit'. Pravdepodobne to tušili i pracovníci SNM, a preto sa rozhodli neinštalovat' zbierky spät' na svoje miesto. Táto obava sa v plnej miere naplnila v apríli 1945, kedy sa očakával prechod frontu cez Turčiansky Sv. Martin. Riaditel' Štátneho archeologického ústavu V. Budinský-Krička sa rozhodol, že ostane v budove SNM a bude chránit' ukryté zbierky, ktoré „z hl’adiska národného i vedeckého“ predstavovali nenahraditel'né hodnoty. Nutnost' zotrvania v ústave uznalo i MŠANO (Archív SAV, AÚ SAV m). Počas prechodu frontu nebol majetok ústavu vôbec poškodený (Archív SAV, AÚ SAV n). Riaditel' ústavu si po skončení bojových akcií začal znovu zariad’ovat' ústavnú pracovňu, usporadúval depozitár s nálezmi a začal opät’ inštalovat' archeologické zbierky (Archív SAV, AÚ SAV o; p).

\section{Do nového sveta - nový štatút}

Po skončení vojny sa začali ozývat' hlasy, že pôsobnost' a kompetencie ústavu neboli v pôvodnom štatúte ústavu z roku 1942 dostatočne upravené. Vytvárala sa tým cesta k riadnemu právnemu zakotveniu dovtedy jedinej inštitúcie profesionálne sa venujúcej archeológii na území Slovenska. Táto otázka sa začala riešit' už v roku 1946. Nový štatút ústavu bol schválený Slovenskou národnou radou až koncom roka 1947 (Národnie noviny 1948). Schváleniu predchádzala odborná diskusia, do ktorej bolo zapojených viacero inštitúcií. Okrem samotného Štátneho archeologického 
ústavu sa k obsahu štatútu vyjadrovalo Slovenské múzeum v Bratislave a Umelecká a vedecká rada. O zmeny v novom štatúte sa snažil aj riaditel' pražského archeologického ústavu - Jaroslav Böhm. V liste A. Točíkovi naznačoval vhodnost' prebratia viacerých bodov zo štatútu pražského ústavu. Ako uviedol J. Böhm, ,bylo by velmi výhodné, kdyby Vášs statut byt shodný (...) a ještě výhodnějši by bylo, kdyby z Vašeho podnětu došlo k formálnímu sloučení obou ústavů pod jedno záhlavi“" (Archív SAV, AÚ SAV q). Účelom tohto kroku malo byt' následné zlúčenie oboch ústavov - slovenského i českého - na platforme spoločného Archeologického ústavu Československej republiky. Oba ústavy si mali pritom zachovat' rozpočtovú, personálnu i kompetenčnú samostatnost', v spoločných záležitostiach ako i navonok mali vystupovat' spoločne podl'a predchádzajúcej dohody. Tento zámer nebol nakoniec realizovaný. Uprednostnilo sa vypracovanie nového štatútu, ktorý mohli pripomienkovat' viaceré inštitúcie. Ako základ poslúžil starý štatút z roku 1942. V. Budinský-Krička rozšíril znenie paragrafu č. 2, podla ktorého mal ústav vykonávat' sústavné výskumy a dozerat' nielen na prehistorické nálezy, no i náleziská. Dotkol sa i témy spolupracovníkov ústavu, s ktorými mal riaditel' ústavu hojné (a v prevažnej miere pozitívne) skúsenosti. Vd’aka tomu sa mu týchto „zaslúžilých priaznivcov archeologického výskumu“ podarilo pevne začlenit” medzi spolupracovníkov ústavu (Archív SAV, AÚ SAV r).

Zásadnejšie pripomienky $\mathrm{k}$ novému štatútu sa podarilo pripojit' Slovenskému múzeu v Bratislave. Za sídlo ústavu sa mu podarilo presadit' Bratislavu s tým, že Povereníctvo školstva a osvety mohlo zriadit' „odbočku“, ktorá však mala podliehat' bratislavskému ústrediu (v návrhu bol ako sídlo „odbočky“ uvedený Turčiansky Sv. Martin, no do definitívneho znenia štatútu sa napokon dostali Košice). Medzi povinnosti Štátneho archeologického ústavu bola zaradená aj inventarizácia a konzervácia nálezov, resp. dozor nad nimi. Ako opodstatnená bola do návrhu pridaná povinnost' udelit' povolenie realizátorovi archeologického výskumu, a to priamo od Štátneho archeologického ústavu (Archív SAV, AÚ SAV s). Povereníctvo školstva a osvety poslalo návrh osnovy nového nariadenia aj Umeleckej a vedeckej rade, ktorá pripojila len niekol'ko formálnych pripomienok.

Argumentácia pre formulovanie jednotlivých bodov štatútu bola rozvinutá v dôvodovej správe. Obšírne a podrobné je zdôvodnenie presunu sídla ústavu do Bratislavy. Určujúca bola početná prítomnost' prehistorických a protohistorických nálezísk na južnom Slovensku v povodí Moravy, Váhu, Nitry, Žitavy a Hrona. Ďalším dôvodom presunu mala byt' zvýšená nutnost' kontaktu s vysokoškolským prostredím, ako i možnost' spolupráce s pomocnými vedeckými disciplínami, stavebnými úradmi a povereníctvami. Presunom do Bratislavy by sa vyriešili i priestorové problémy ústavu. V Turčianskom Sv. Martine mal ŠAÚ v budove Slovenského národného múzea k dispozícii len jednu miestnost', zatial' čo v rekonštruovanej a adaptovanej budove Slovenského múzea $\mathrm{v}$ Bratislave boli $\mathrm{k}$ dispozícii administratívne miestnosti, konzervačné a preparačné laboratóriá spoločne $\mathrm{s}$ fotoateliérom. Pobočka ústavu v Košiciach tiež nebola vybraná náhodne - za týmto rozhodnutím stáli ako vedecké, tak i politické dôvody. Jej budovanie malo začat’ až po tom, čo sa prest’ahuje sídlo ústavu do Bratislavy a bude ukončená jeho organizácia. Zaujímavé je sledovanie politického motívu v pozadí vzniku košickej pobočky. Už od čias Uhorského král'ovstva bola na východné Slovensko upretá pozornost' mnohých mad’arských bádatel'ov. Príčinou bola prítomnost' najstarších archeologických dokladov o pobyte staromad’arských kmeňov na území Karpatskej kotliny. Navyše nebolo možné v tom čase preukázat' historickými správami „slovanskost"“ tohto územia pred 7. storočím n. 1. Presunom t’ažiska pozornosti archeológov na túto oblast' tak mali byt' postupne zapĺn̆ané biele miesta na archeologickej mape Slovenska.

\section{Personálne, priestorové a finančné zabezpečenie ústavu}

S obnovením Československej republiky sa do pozornosti dostala otázka personálneho obsadenia ústavu. To sa počas vojny vôbec nemenilo či nerozširovalo. Okrem samotného riaditel’a bol $\mathrm{v}$ ústave zamestnaný len jeden zamestnanec - A. Rajnič. To sa však malo zakrátko zmenit'. Povereník vnútra po dohode s povereníkom pre školstvo a osvetu navrhli na zasadnutí Predsedníctva 
Zboru povereníkov, ktoré sa konalo 10. októbra 1947, novú systematizáciu pracovných miest v Štátnom archeologickom ústave. Podla tohto návrhu mohol ústav v najbližšom období počítat' s niekol'konásobným zvýšením počtu svojich zamestnancov (konkrétne malo íst' o štyroch úradníkov správnej osvetovej služby, troch úradníkov nižšej pomocnej služby, jedného úradníka kancelárskej služby, jedného úradníka kancelárskej pomocnej služby a jedného zriadenca; Archív SAV, AÚ SAV t). Rozhodnutie Predsedníctva Zboru povereníkov bolo V. Budinským-Kričkom prijaté mimoriadne kladne. Na systematizované miesta mali byt' ustanovení v prvom rade už existujúci zamestnanci. Išlo predovšetkým o A. Rajniča, ktorý sa na začiatku júna 1945 vrátil z nemeckého zajatia (Archív SAV, AÚ SAV u). Žiadost' o prijatie do ústavu podal aj Anton Točík, ktorý dovtedy pôsobil na Povereníctve školstva a osvety ako komisár v odbore pre ochranu pamiatok (Kolníková a kol. 2000, 8). Od 1. januára 1948 sa tak dovtedajšie personálne obsadenie ústavu zdvojnásobilo - ministerským koncipistom správnej a osvetovej služby sa stal už spomínaný A. Točík a na post nižšej pomocnej technickej služby nastúpil dlhoročný spolupracovník ústavu Andrej Škvarek (Archív SAV, AÚ SAV v). Realizované rozšírenie pracovného kolektívu v Štátnom archeologickom ústave, zd’aleka nenapíňajúce smelú víziu Predsedníctva Zboru povereníkov, nedokázalo pokrývat' dlhodobé potreby ústavu. Pravdepodobne aj preto sa V. Budinský-Krička rozhodol nadviazat' na už overený koncept tajomníkov, ktorý začal úspešne fungovat' už počas vojnových rokov. Siet' tajomníkov sa oproti predošlému stavu značne obmenila a predovšetkým rozšírila. Z predchádzajúceho výberu si poverenie podržali len Šarlota Križanová a Dezider Tomeček. Doplnila ich skupina mladých gymnaziálnych profesorov, riaditelov, školských inšpektorov či kultúrnych pracovníkov. Patrili medzi nich napríklad Belo Polla, Ján Pástor, Pavol Čaplovič či Mikuláš Dušek (Archív SAV, AÚ SAV w).

Každodenný chod ústavu však stále spočíval na pleciach štyroch stálych zamestnancov. Aj v dôsledku toho uviedol riaditel' ústavu v dôvodovej správe k rozpočtu na rok 1949, že výsledky, ktoré ústav v predchádzajúcom období dosiahol, sú dielom vrcholného vypätia jednotlivcov a ich sebaobetovania (Archív SAV, AÚ SAV x). Na odbremenenie zamestnancov preto navrhoval prijat' ešte d’alších troch pracovníkov. Systemizáciou nových miest však boli kladené zvýšené nároky nielen na osobné výdaje, no aj na zariadenie a vybavenie ústavu. Ešte v roku 1948 bol totiž ústav vybavený len jedným písacím stolom, jednou skriňou, jedným písacím strojom a jedným fotoaparátom. Ostatné zariadenie, ako aj samotné miestnosti ešte vždy zaist'ovalo SNM - ústav provizórne využíval priestory v suteréne múzea a kancelárie kustódov (Archív SAV, AÚ SAV y). Nevyhovujúce boli aj pridelené dotácie na archeologický výskum, potrebný kancelársky materiál, doṕ́ňanie knižničného fondu či preplácanie cestovného.

Tlak na riešenie priestorových problémov ústavu d’alej vystupňovalo poštátnenie SNM. Možnost' prijímania nových múzejných zamestnancov nutne otvárala otázku d'alšieho zotrvania ústavu na jeho dovtedajšom pôsobisku. Do úvahy pripadal i presun do Bratislavy, ako to napokon predpokladal i nový štatút. Nakoniec bolo s pomocou Povereníctva školstva, vedy a umení získané nové pôsobisko - kaštiel' v ned’alekej Bystričke, ktorý pred vojnou využívala rodina Masarykovcov ako svoje letné sídlo (Archív SAV, AÚ SAV z). Ústav tak s účinnost'ou od 1. novembra 1949 zmenil svoje sídlo. Prispôsobenie budovy novému účelu si však vyžadovalo nemalé úpravy. Z pracovne J. Masaryka sa stala pracovňa riaditela ústavu, jedna zo spální bola prebudovaná na konzervačnú pracovňu s regálmi na uloženie spracovaného archeologického materiálu, d’alšia spálňa sa mala zmenit' na kanceláriu a kresliareň. Miestnosti pod manzardovou strechou mali byt' využité ako byty pre slobodných zamestnancov a ako skladiská (Archív SAV, AÚ SAV aa). Značný zásah do interiéru i exteriéru si vyžadovala údržba budovy. Pre napadnutie stien hudobnej sály, Masarykovej pracovne a chodby hubou boli steny uvedených miestností navítané a napustené petrolejom. Opravy si tiež vyžadovala terasa nad halou a zatekajúca strecha (Archív SAV, AÚ SAV ab).

Povojnové finančné zabezpečenie ústavu sa tiež postupne zlepšovalo. Za rok 1946 bolo na archeologický výskum poskytnutých 36750 Kčs, o rok neskôr to bolo 58 859,50 Kčs. Niekol'konásobný nárast štátnej dotácie nastal až v roku 1948, kedy bolo ústavu pridelených 262000 Kčs. 
Nasledujúci rok bolo ústavu zabezpečené i materiálne a technické vybavenie, a to vo výške 373288 Kčs. K tomu treba ešte prirátat' dotáciu na výskum, ktorá v tomto roku činila 735172 Kčs (Archív SAV, AÚ SAV aa). V nasledujúcom období mali byt' štátne dotácie pridel’ované na základe pätročného plánu (Archív SAV, AÚ SAV ac). V. Budinský-Krička preto rozplánoval úlohy na nasledujúce obdobie a pridelil im aj zodpovedajúcu finančnú položku. Najväčšia suma (až 1 milión Kčs) bola vyčlenená na výskum slovanských hradísk (ak neberieme do úvahy výskum rímskeho tábora v Iži, na ktorý mala byt' pridelená rovnako vysoká suma). Toto zameranie malo v dobovom kontexte nepochybne i politické rozmery, čo V. Budinský-Krička otvorene priznal v dôvodovej správe zriadenia Štátneho archeologického ústavu (Archív SAV, AÚ SAV ad). Polovičná suma (500 $000 \mathrm{Kčs}$ ) bola pridelená na výskumy najstarších stavebných pamiatok v rámci historickej archeológie.

\section{Osudové 50. roky}

V. Budinskému-Kričkovi, ktorý viedol ústav počas vojnových rokov i v nasledujúcom povojnovom období, už nebolo dopriate naplno zažit’ jeho rozvoj podporený výdatnými štátnymi subvenciami. V apríli 1951 bol zatknutý a uväznený za údajnú protištátnu činnost', čo mu znemožnilo osobne viest' chod ústavu (Kalina 2017). Jeho vedením bol poverený pracovník Matice slovenskej Ján Dekan. Po krátkom pôsobení na ústave však odišiel do Bratislavy, kde sa ujal funkcie predsedu Historického ústavu Slovenskej akadémie vied a umení (Vladár 2005, 17). Skutočné vedenie tak spočinulo na pleciach A. Točíka. A bol to práve on, kto zabezpečil presun sídla ústavu do jeho nového pôsobiska - na Nitriansky hrad. Výber tohto miesta nebol vôbec náhodný. A. Točík poznal Nitriansky hrad už od svojho pôsobenia na Povereníctve školstva a osvety, kde sa podiel'al na jeho obnove (Kolníková a kol. 2000, 10). Prestavba a akomodácia druhého poschodia hradného paláca pre účely ústavu sa začala už v októbri 1952, st’ahovanie nasledovalo na počiatku roka 1953 (Archív SAV, AÚ SAV ae). Tento rok bol zároveň i prelomovým v organizácii samotného ústavu v rámci vedy v Československu. Prijatím zákona o Slovenskej akadémii vied bol Štátny archeologický ústav, teraz už pod novým názvom ako Archeologický ústav, začlenený do štruktúry SAV. Tým sa začala nová etapa v dejinách Archeologického ústavu, ktorý až do súčasnosti výrazne ovplyvňuje archeologické bádanie na Slovensku.

\section{Archívne pramene}

Archív SAV, AÚ SAV: Archív SAV, f. AÚ SAV - Personálna agenda, zn. B X, 1946, inv. č. 364, škat. č. 68. Archív SAV, AÚ SAV a: Archív SAV, f. AÚ SAV - Vedenie ústavu, zn. B II, 1939, inv. č. 92, č. j. 1/1939, škat. č. 4.

Archív SAV, AÚ SAV b: Archív SAV, f. AÚ SAV - Vedenie ústavu, zn. B II, 1939, inv. č. 92, č. j. 2/1939, škat. č. 4.

Archív SAV, AÚ SAV c: Archív SAV, f. AÚ SAV - Rozpočet a systematizácia, zn. B XV, 1940, inv. č. 460, č. j. 31/40, škat. č. 81 .

Archív SAV, AÚ SAV d: Archív SAV, f. AÚ SAV - Rozpočet a systematizácia, zn. B XV, 1945, inv. č. 465, č. j. 70/1945, škat. č. 81 .

Archív SAV, AÚ SAV e: Archív SAV, f. AÚ SAV - Rozpočet a systematizácia, zn. B XV, 1940, inv. č. 460, č. j. 116/1940, škat. č. 81.

Archív SAV, AÚ SAV f: Archív SAV, f. AÚ SAV - Rozpočet a systematizácia, zn. B XV, 1940, inv. č. 460, č. j. 125/1940, škat. č. 81 .

Archív SAV, AÚ SAV g: Archív SAV, f. AÚ SAV - Rozpočet a systematizácia, zn. B XV, 1943, inv. č. 463, č. j. 86/1943, škat. č. 81 .

Archív SAV, AÚ SAV h: Archív SAV, f. AÚ SAV - Rozpočet a systematizácia, zn. B XV, 1942, inv. č. 462, škat. č. 81. 
Archív SAV, AÚ SAV i: Archív SAV, f. AÚ SAV - Rozpočet a systematizácia, zn. B XV, 1943, inv. č. 463, č. j. 407/1943, škat. č. 81 .

Archív SAV, AÚ SAV j: Archív SAV, f. AÚ SAV - Rozpočet a systematizácia, zn. B XV, 1942, inv. č. 462, č. j. 45/1942, škat. č. 4.

Archív SAV, AÚ SAV k: Archív SAV, f. AÚ SAV - Vedenie ústavu, zn. B II, 1942, inv. č. 95, škat. č. 4.

Archív SAV, AÚ SAV 1: Archív SAV, f. AÚ SAV - Vedenie ústavu, zn. B II, 1944, inv. č. 96, č. j. 327/1944, škat. č. 4.

Archív SAV, AÚ SAV m: Archív SAV, f. AÚ SAV - Vedenie ústavu, zn. B II, 1945, inv. č. 97, č. j. 31/1945, škat. č. 4.

Archív SAV, AÚ SAV n: Archív SAV, f. AÚ SAV - Vedenie ústavu, zn. B II, 1945, inv. č. 97, č. j. 92/1945, škat. ̌̌. 4.

Archív SAV, AÚ SAV o: Archív SAV, f. AÚ SAV - Vedenie ústavu, zn. B II, 1945, inv. č. 97, č. j. 56/1945, škat. č. 4.

Archív SAV, AÚ SAV p: Archív SAV, f. AÚ SAV - Vedenie ústavu, zn. B II, 1945, inv. č. 97, č. j. 57/1945, škat. č. 4.

Archív SAV, AÚ SAV q: Archív SAV, f. AÚ SAV - Vedenie ústavu, zn. B II, 1947, inv. č. 99, č. j. 7232/47, škat. č. 4.

Archív SAV, AÚ SAV r: Archív SAV, f. AÚ SAV - Vedenie ústavu, zn. B II, 1946, inv. č. 98, č. j. 137/46, škat. č. 4.

Archív SAV, AÚ SAV s: Archív SAV, f. AÚ SAV - Vedenie ústavu, zn. B II, 1946, inv. č. 98, č. j. 258/46, škat. č. 4.

Archív SAV, AÚ SAV t: Archív SAV, f. AÚ SAV - Rozpočet a systemizácia zn. B XV, 1947, inv. č. 467, č. j. 505/1947, škat. č. 81 .

Archív SAV, AÚ SAV u: Archív SAV, f. AÚ SAV - Personálna agenda, zn. B X, 1945, inv. č. 363, škat. č. 68. Archív SAV, AÚ SAV v: Archív SAV, f. AÚ SAV - Personálna agenda, zn. B X, 1946, inv. č. 364, škat. č. 68. Archív SAV, AÚ SAV w: Archív SAV, f. AÚ SAV - Personálna agenda, zn. B X, 1948, inv. č. 365, škat. č. 68. Archív SAV, AÚ SAV x: Archív SAV, f. AÚ SAV - Rozpočet a systemizácia, zn. B XV, 1948, inv. č. 468, č. j. 368/1948, škat. č. 81 .

Archív SAV, AÚ SAV y: Archív SAV, f. AÚ SAV - Rozpočet a systemizácia, zn. B XV, 1949, inv. č. 469, č. j. 549/1949, škat. č. 81 .

Archív SAV, AÚ SAV z: Archív SAV, f. AÚ SAV - Rozpočet a systemizácia, zn. B XV, 1949, inv. č. 469, č. j. 944/1949, škat. č. 81 .

Archív SAV, AƯ SAV aa: Archív SAV, f. AÚ SAV - Výročné správy, zn. B IV, 1950, inv. č. 175, bez č., škat. č. 18 .

Archív SAV, AÚ SAV ab: Archív SAV, f. AÚ SAV - Rozpočet a systemizácia, zn. B XV, 1951, inv. č. 471, č. j. 1578/51, škat. č. 81 .

Archív SAV, AÚ SAV ac: Archív SAV, f. AÚ SAV - Rozpočet a systemizácia, zn. B XV, 1948, inv. č. 468, č. j. 231/1948, škat. č. 81 .

Archív SAV, AÚ SAV ad: Archív SAV, f. AÚ SAV - Vedenie ústavu, zn. B II, 1946, inv. č. 98, bez č., škat. č. 4.

Archív SAV, AÚ SAV ae: Archív SAV, f. AÚ SAV - Vedenie ústavu, zn. B II, 1952, inv. č. 103, č. j. 767, škat. č. 4 .

\section{Literatúra}

BIANCHI, L. a kol., 1973: Dejiny štátu a práva na území Československa v období kapitalizmu II. 1918-1945. Bratislava.

GERYK, J., 1929: Zápisnica, Časopis Muzeálnej slovenskej spoločnosti 21, 129-134.

- 1933: Zápisnica, Časopis Muzeálnej slovenskej spoločnosti 25, 31-33.

- 1933a: Zápisnica, Časopis Muzeálnej slovenskej spoločnosti 25, 66-74. 
- 1935: Zápisnica, Časopis Muzeálnej slovenskej spoločnosti 26, 49-51.

- 1946: Výročná zpráva o činnosti Muzeálnej slovenskej spoločnosti, Časopis Muzeálnej slovenskej spoločnosti 36-37, č. 1, 9-14.

- 1946a: Slovenské národné múzeum za nemeckej okupácie, Časopis Muzeálnej slovenskej spoločnosti 36-37, č. 1, 6-9.

HALMOVÁ, M., 2015: Muzeálna slovenská spoločnost' a Slovenské národné múzeum v rokoch 1939-1945. In: Múzeá vo vojne. Druhá svetová vojna a jej dôsledky na činnost' múzeí a ich zbierky (Podušelová, G.Majchrovičová, V., edd.), 5-14. Banská Bystrica.

HYČKO, J.-OKÁLI, I.-POLLA, B., 1968: Slovenské národné múzeum. Bratislava.

JURKOVIČ, M., 1945: Slovenské národné múzeum v Turč. Sv. Martine - Das Slowakische Nationalmuseum in Turč. Sv. Martin - Le Musée National à Turč. Sv. Martin. In: Slovenské múzeá. Ich vznik a prehl’ad sbierok, 13-24. Bratislava.

KALINA, J., 2017: Okolnosti uväznenia a odsúdenia profesora Vojtecha Budinského-Kričku - The Circumstances of Imprisonment and Conviction of Professor Vojtech Budinský-Krička. In: 95 rokov Filozofickej fakulty UK. Pohlad do dejín inštitúcie a jej akademickej obce (Slobodník, M.- Glossová, M., edd.), 355-366. Bratislava.

KOLNÍKOVÁ, E. a kol., 2000: Anton Točík 1918-1994. Biografia. Bibliografia. Nitra.

KUJOVSKÝ, R.-VLADÁR, J., 2013: História bádania. In: Staré Slovensko 1. Archeológia ako historická veda (Bujna, J.-Furmánek, V.-Wiedermann, E., edd.), 183-197. Nitra.

NÁRODNIE NOVINY, 1948: Štátny archeologický ústav napreduje, roč. 79, 21. január 1948, č. 16, 5.

NEUMANN, M., 2019: Rok 1939 v slovenskej archeológii - Year 1939 in Slovak archaeology, Musaica archaeologica 4, č. 2, 7-26.

OLIVA, M.-KOSTRHUN, P., 2019: Česká archeologie pod jhem nacismu ve světle interetnických vztahů Czech archaeology under the yoke of Nazism in light of interethnic relations, AR LXXI, 105-137.

PAVÚK, J., 2004: Odišiel Andrej Rajnič, SlArch LII, 187-188.

POLLA, B., 1989: Prvý archeologický ústav na Slovensku (K 50. výročiu založenia), ZbSNM 83, História $29,125-142$.

PREHLAD PRÁC, 1940: Prehlad prác v Slovenskom národnom múzeu (1939), Časopis Muzeálnej slovenskej spoločnosti 31, č. 2, 26-32.

STARCOVÁ, M., 2019: Za okupace. StAÚ v letech 1939-1945. In: Kuna, M.-Starcová, M.- Maříková-Kubková, J. a kol., Sto let v archeologii. Objevy, nálezy a expedice Archeologického ústavu v Praze 1919-2019 - A hundred years in archaeology: discoveries, finds and expeditions of the Institute of Archaeology in Prague 1919-2019, 68-69. Praha.

VLADÁR, J., 2005: Akademik Ján Dekan. Archeológ, polyhistor a humanista. In: Vladár, J., Ján Dekan. Život a dielo, 17-22. Nitra.

VLÁDNE NARIADENIE, 1938: Vládne nariadenie zo dňa 23. decembra 1938 o úprave niektorých služobných pomerov štátnych zamestnancov so zretel’om k autonómii krajiny Slovenskej.

VÝROČNÁ SPRÁVA, 1939: Výročná správa o činnosti Muzeálnej slovenskej spoločnosti r. 1938, Časopis Muzeálnej slovenskej spoločnosti 30, č. 2, 28-32.

\section{Zusammenfassung}

\section{Das Staatliche archäologische Institut in Turz-Sankt Martin in den Jahren 1939-1953}

Die Anfänge des Staatlichen archäologischen Instituts in Turz-Sankt Martin hängen eng mit den Verstaatlichungsbemühungen des Slowakischen Nationalmuseums Ende der dreißiger Jahre des 20. Jahrhunderts zusammen. $\mathrm{Zu}$ diesem Schritt haben die Museumsverwaltung vor allem Probleme bewegt, die mit einer ordentlichen Finanzierung des Museumsbetriebs, bzw. seiner sich um die einzelnen Sammlungen kümmernden Kustoden zusammenhingen. Eine erfolgreiche Lösung dieses Problems wurde zunächst durch zum Jahresende 1938 erfolgte staatsrechtliche 
Veränderungen vereitelt. Auf Initiative des Verwalters des Slowakischen Nationalmuseums Ján Geryk ist es schließlich gelungen, die Entstehung eines eigenständigen Staatlichen archäologischen Instituts durchzusetzen. Seine Wirkungsstätte sollte das Institut am Slowakischen Nationalmuseum haben, dessen Räume und Einrichtungen es benutzen sollte. Zum ersten Direktor des Instituts wurde Vojtech Budaváry (später Budinský-Krička) berufen, der mit anfänglichen personellen und finanziellen Problemen des Instituts kämpfen musste. Trotz allem ist es ihm gelungen, eine bemerkenswerte Tätigkeit zu entfalten, die fast das gesamte Gebiet der damaligen Slowakei abdeckte. Beträchtliche Hilfe erhielt er auch durch ein Netzwerk an Sekretären, die das Staatliche archäologische Institut in ihren Regionen vertreten haben. Die turbulenten Ereignisse der ersten Hälfte der vierziger Jahre haben auch das Leben des Instituts bedroht. Der Slowakische Nationalaufstand und der Durchzug der Front erforderten das Ergreifen besonderer Maßnahmen, deren Ziel vor allem aus dem Schutz der Sammlungsgegenstände bestand. Der Betrieb des Instituts wurde erst nach Kriegsende wieder aufgenommen. Man begann auch damit, die finanziellen und personellen Probleme des Instituts zu klären, wenn auch nur in einem sehr langsamen Tempo. Die Höhe der staatlichen Zuschüsse für die Tätigkeit des Instituts hat erst im Jahr 1948 wesentlich zugenommen. Durch den Umzug des Instituts in die sich in der Nähe von Turz-Sankt Martin in Bystrička befindende ehemalige Sommerresidenz von T. G. Masaryk wurde auch die akute Raumfrage gelöst. Vojtech Budinský-Krička war als Direktor des Instituts jedoch nicht genügend Zeit vergönnt, es in die neue Nachkriegszeit zu führen. Im Jahr 1951 wurde er wegen einer angeblichen antistaatlichen Tätigkeit angeklagt und in Ilava inhaftiert. Nach kurzer Tätigkeit von Ján Dekan an der Spitze des Instituts wurde dessen Leitung auf Anton Točík übertragen. Mit seiner Person begann in der Geschichte des Instituts eine neue Ära, die äußerlich in der Verlegung des Institutssitzes nach Nitra sowie durch seine endgültige Eingliederung in die Stukturen der Slowakischen Akademie der Wissenschaften ihren Ausdruck fand.

Mgr. \& Mgr. Martin Neumann, PhD., Katedra archeológie Filozofickej fakulty Univerzity Komenského v Bratislave, Gondova 2,81102 Bratislava, Slovenská republika, martin.neumann@uniba.sk 